\title{
NATIONAL PHYSICAL LABORATORY RADIOCARBON MEASUREMENTS VI
}

\author{
W. J. CALLOW and GERALDINE I. HASSALL
}

National Physical Laboratory, Teddington, England

The following list comprises measurements made since those reported in NPL V.

No changes have been made in measurement technique or in the method of calculating results described in NPL III.

Ages are given relative to A.D. 1950 and a half-life of 5568 yr has been assumed. Measurements, corrected for fractionation relative to the P.D.B. standard, are referred to 0.950 times the activity of the NBS oxalic acid as contemporary reference standard. The quoted uncertainty is one standard deviation and includes an additional uncertainty equivalent to a standard deviation of $80 \mathrm{yr}$ for the de Vries effect, but excludes the uncertainty of the half-life. Should a net sample count rate be less than 4 times the standard error of the difference between the sample and background count rates a lower limit to the age would be reported corresponding to a net sample count rate of 4 times the standard error of this difference.

The description of each sample is based on information supplied to the laboratory by the person submitting the sample.

ARCHAEOLOGIC AND GEOLOGIC SAMPLES

\section{A. England}

\section{Oxbow Opencast Coal site, Yorkshire}

Incisor (tusk) of (Mammuthus (Elephas) primigenius) from silt bed within gravels at Oxbow Opencast Coal site $\left(53^{\circ} 46^{\prime} 02^{\prime \prime} \mathrm{N}\right.$ Lat, $01^{\circ}$ $28^{\prime} 04^{\prime \prime}$ W Long), in Aire Valley near Leeds, Yorkshire. Coll. 1964 and subm. by G. D. Gaunt, Inst. of Geol. Sci. Comment (G.D.G.): stratigraphical position of silt bed suggests deposition during Weichselian Glaciation some time prior to phase of crysturbation diagnostic of extremely cold conditions. Included insect and floral remains, examined by G. R. Coope (Univ. of Birmingham) and J. W. Franks (Univ. of Manchester) respectively, indicate a tundra environment, insects being similar to those from Brandon Terrace, Warwickshire (NPL-87, 28,200 \pm 500 ; NPL-IV), Tame Valley, Warwickshire and Fladbury, Worcestershire, (GrN-1269, 38,200 \pm 700 ; GrN VI), all referable to the 'Upton Warren Interstadial.' Although tusk may have been derived and therefore older than silt bed, date still falls within range of this interstadial (Coope and Sands, 1966).

NPL-163 A. Oxbow site

Calcium carbonate from outer part of tusk. Yielded age ca. 10,000 yr. 


\section{NPL-163 B. Oxbow site

Organic carbon fraction from inner part of tusk.

\section{NPL-163 C. Oxbow site}

Organic carbon fraction from outer part of tusk.

\section{NPL-126. Middle Hope, Weston Super Mare, Somerset}

Shell fragments from raised beach at N Side Middle Hope $\left(51^{\circ} 22^{\prime}\right.$ N Lat, $2^{\circ} 59^{\prime} \mathrm{W}$ Long), Weston Super Mare. Coll. 1965 and subm. by Prof. A. Wood, Univ. College of Wales, Aberystwyth. Comment (A.W.): this unconsolidated shell-sand represents beach deposit of Swallow Cliff time, corresponding to main aggradation of Severn. Date confirms those suggested by Donovan in 'Sea Levels of the Last Glaciation' (Donovan, 1962).

\begin{tabular}{|c|c|}
\hline & $38,990+1690$ \\
\hline $\begin{array}{l}\text { NPL-126 A. Middle Hope } \\
\text { Inner fraction. }\end{array}$ & 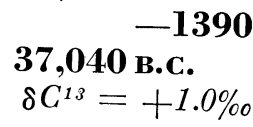 \\
\hline & $33,240+760$ \\
\hline NPL-126 B. Middle Hope & 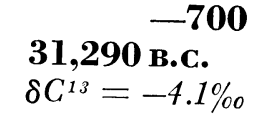 \\
\hline
\end{tabular}

Middle fraction. Comment (W.J.C. and G.I.H.): $1 / 3$ of sample was leached away and from remaining $2 / 3$, two samples were prepared, called inner and middle. The difference in ages for these samples suggests contamination and dates must be regarded as notional only.

\section{Devoke Water series, SW Cumberland}

Samples from core of lake mud from Devoke Water (54 $21^{\prime} \mathrm{N}$ Lat, $3^{\circ} 16^{\prime} \mathrm{W}$ Long), between valleys of rivers Duddon and Esk, S.W. Cumberland. Coll. 1965 and subm. by Winifred Pennington (Mrs. T. G. Tutin), Bot. Dept., Univ. of Leicester. Comment (W.P.): although inversion of relative age of sediments is not uncommon in this district, consistent dates have been obtained in history of Devoke Water, substantiating Late Romano-British age of major episode of clearance (Pennington, 1964); this dismisses possibility that cause of accelerated soil erosion at this horizon was general climatic deterioration, cleduced from 
accelerated growth of peat bogs between 800 and 500 B.c. more than 1000 yr earlier. This series of dates, together with evidence previously obtained, shows that at alt. of Devoke Water, viz., $766 \mathrm{ft}$, dominant factor determining course of soil history and lake sediments was modification of vegetation type, which can only be interpreted as brought about by man (Pennington, 1964).

\section{NPL-117. Devoke Water 1, depth} 220 to $230 \mathrm{~cm}$

$$
\begin{aligned}
& \mathbf{1 7 5 0} \pm \mathbf{1 3 0} \\
& \text { A.D. 200 } \\
& \delta C^{13}=-25.2 \%
\end{aligned}
$$

Represents pre-erosion period of temporary forest clearance; subsequent regeneration of birch and oak, and persistence of elm, indicates this episode was not accompanied by severe soil degradation.

NPL-118. Devoke Water 2, depth

$$
200 \text { to } 210 \mathrm{~cm}
$$

$1370 \pm 190$

A.D. 580

Represents horizon of forest regeneration after clearance of Sample 1 and immediately before main erosion episode. Date shows last time at which soil and climate at this site permitted forest regeneration. Sample diluted, and no $\delta \mathrm{C}^{13}$ measurement made.

\section{NPL-119. Devoke Water 3, depth 185 to $195 \mathrm{~cm}$}

$1585 \pm 130$

A.D. 365

$\delta C^{13}=-20.3 \%$

Represents horizon of inwash of mineral soil and mor humus rich in Calluna pollen. This coincides with episode of forest clearance of much more extensive character than any previous clearance, and with 1st appearance of continuous curve for pollen of cultivated cereals, sample represents end of continuous curve for Ulmus pollen at this site. For this reason alone date is of interest.

\section{NPL-120. Devoke Water 4, depth 167 to $177 \mathrm{~cm}$}

$$
1620 \pm 130
$$

Immediately above erosion horizon from within same vegetation episode as Sample 3, with non-tree pollen dominant, and continuous curves for pollen of clearance indicators, plantain, bracken, and cultivated cereals.

\section{NPL-116. Burnmoor Tarn, SW Cumberland}

$$
\begin{array}{r}
1560 \pm 130 \\
\text { A.D. } 390
\end{array}
$$

Lake mud from core at depth 137 to $147 \mathrm{~cm}$ below mud surface from Burnmoor Tarn (54 $25^{\prime} \mathrm{N}$ Lat, $3^{\circ} 15^{\prime} \mathrm{W}$ Long), at alt. $832 \mathrm{ft}$ between river valleys of Eskdale and Wasdale, SW Cumberland. Coll. 1965 and subm. by Winifred Pennington. Comment (W.P.): date obtained is consistent, as was expected, with dates from Devoke Water 
NPL-117 to NPL-120 (of this list) and supports contemporaneity of these 2 sites. At both sites visible change in stratigraphy of lake sediments at this horizon indicates major change in erosion rate of drainage basin (Pennington, 1965).

\section{NPL-124. Seathwaite Tarn (ii), $N$ Lancashire \\ $3040 \pm 140$ \\ 1090 B.c. \\ $\delta C^{13}=-27.2 \%$} from Seathud valley of Tarn Tarn (54० $22^{\prime} \mathrm{N}$ Lat, $3^{\circ} 9^{\prime} \mathrm{W}$ Long), at alt. $1210 \mathrm{ft}$ in Pennington. Comeck, N Lancashire. Coll. 1965 and subm. by Winifred tion history of NPL 117 to NPI accompanied partial and NPL-116. Accelerated erosion of mineral soils distribution of this clearorestation at this horizon. Date is consistent with are frequent (Pennington, 1964).

\section{Grimthorpe series, E Riding, Yorkshire}

Sample from 2 unidentified animal bones from ditch of Iron-age hillfort, assoc. with Iron-age pottery at Grimthorpe (53० $55^{\prime} 36^{\prime \prime}$ N Lat, $0^{\circ} 45^{\prime} 12^{\prime \prime}$ W Long), Yorkshire. Coll. 1961 by I. M. Stead and subm. by
L. Biek, Ministry of Public Buildings and Works.

General Comment (I.M.S.): there are few established landmarks in British Iron-age chronology, and dating of pottery without assoc. metalwork can be proposed only in very broad terms. Both dates are considerably earlier than expected from archaeologic evidence, viz., between 400 в.C. and 100 в.C. (Stead and Dymond, 1959).

\section{NPL-136. Grimthorpe}

$$
\begin{gathered}
2640 \pm 130 \\
690 \text { в.C. }
\end{gathered}
$$

Sample G. Br., found a few ft immediately above NPL-137.

\section{NPL-137. Grimthorpe}

$2920 \pm 130$

Sample G. Ca., found a few ft immediately below NPL-136.

$$
970 \text { в.C. }
$$

$\delta C^{13}=-22.2 \%$

\section{NPL-115. Braunton Burrows, N Devon}

Barnacles (Balanus balanoides) from surface of $>\mathbf{4 0 , 8 0 0}$ form at Braunton Burrows $\left(51^{\circ} 07^{\prime} 06^{\prime \prime}\right.$ Devon. Coll. 1965 by A. Heyworth and subm. by Prof. C. Kidson, Univ.
College of Wales, Aberystwyth. College of Wales, Aberystwyth. Comment (C.K.): shells from beneath raised beach deposits of concreted sand overlain by head. Date suggests platform may be Eemain in age, but it could equally be older. Date throws little light on age of raised beach deposits. 
B. Australia

1770

NPL-20. Northampton, Australia

Rostrum of Xiphoid whale id. as Mesoplodon densirostris by J. C. Moore of Chicago from raised beach at Northampton $\left(28^{\circ} 21^{\prime} \mathrm{S}\right.$ Lat, $114^{\circ} 37^{\prime}$ E Long; co-ordinates taken at center of town). Subm. by W. A. M. White for W. D. L. Ride. Comment (W.D.L.R.): catalogued in 1939 as M2362 in mammal collection of W Australia Mus., presented by Mr. R. E. Rob of Northampton, and recorded in catalogue as being "found on the beach," this may or may not refer to Horrocks Beach, most accessible beach from Northampton. Horrocks Beach is backed by coastal limestone, Pleistocene, and would fit very well with result obtained, but geologic provenance must be regarded as "uncertain." In spite of this, knowledge that Mesoplodon densirostris occurred here in post-glacial times is most interesting and there can be little doubt that specimen came from either coastal limestone or from one of calcareous dune system which, when indurated produce coastal limestone (Fairbridge, 1954; Mc.trthur and Bettenay, 1960). Sample diluted, and no $\delta \mathrm{C}^{13}$ measurement made.

\section{Canada}

\section{NPL-114. 'Rivière-aux-Poissons', Sugluk Inlet, Quebec}

Brown fibrous sancly peat containing numerous graminaceous and cyperaceous remains and small woody fragments from cut-back exposure in terrace at alt. $135 \mathrm{ft}$, and depth $9 \mathrm{ft} 81 / 2$ in., near mouth of 'Rivièreaux-Poissons', Sugluk Inlet, (62० 51' N Lat, $75^{\circ} 45^{\prime}$ W Long). Coll. 1965 and subm. by B. Matthews. Comment (B.M.): date older than expected, and gives maximum age for formation, during cool, dry period, of 1 st layer of eolian sand; sample possibly formed during warmer and wetter period.

\section{A.D. 1280}

NPL-125. 'Rivière Tourbe', Sugluk Inlet, Quebec $\delta C^{13}=-24.9 \%$ Sphagnum peat, mainly $S$. acutifolium and occasional twigs of Salix herbacea and Betula glandulosa; some Carex nutlets. Sample from cutback exposure in terrace at alt. $37 \mathrm{ft}$ and depth $7 \mathrm{ft}$, near mouth of 'Rivière Tourbe', at SW end of Sugluk Inlet $\left(62^{\circ} 10^{\prime} \mathrm{N}\right.$ Lat, $75^{\circ} 55^{\prime}$ W Long). Coll. 1965 and subm. by B. Matthews. Comment (B.M.): result gives date for cessation of Sphagnum peat growth and start of cool, dry period during which eolian sand buried peat. Basal (Sphagnum) peat 
from same deposit is $1600 \pm 140$ yr old, (GSC-537, Radiocarbon, 1967, v. 9, p. 179). The 2 dates suggest that wet, mild period indicated in pollen diagrams (Bartley and Matthews, in preparation), coincided with climatic amelioration in Sub-Arctic Central Canada 1500 to $600 \mathrm{yr}$ ago (Nichols, 1967).

\section{Malaysia}

\section{Sungei Besi series, Kuala Lumpur, Malaya}

Two samples of peat and one of wood in sand from location in $\mathrm{N}$ open-cast of Sungei Besi Tin Mines (03 $03^{\prime} \mathrm{N}$ Lat, $101^{\circ} 43^{\prime} \mathrm{E}$ Long), Kuala Lumpur, Selangor. Coll. 1965 by Mohammed bin Ayob and subm. by Prof. N. S. Haile, Univ. of Malaya.

$\begin{array}{lc} & \mathbf{3 6 , 4 2 0}+\mathbf{1 2 5 5} \\ \text { NPL-143. Sungei Besi } & \mathbf{3 4 , 4 7 0} \text { B.C. } \\ & \delta C^{13}=-27.5 \% \\ \text { Brown woody stems, preserved in unconsolidated black peaty } & \text {. }\end{array}$

Brown woody stems, preserved in unconsolidated black peaty sand. Some stems may have been in situ, since they were seen to penetrate stratification boundaries of black peaty sand. Sample taken at alt. $42 \mathrm{ft}$.

NPL-144. Sungei Besi

$8 C^{13}=-29,200$

Dark-brown peat occurring as stratum ca. $1 \mathrm{ft}$ thick in interstratified mud and sand at alt. ca. $40 \mathrm{ft}$.

NPL-145. Sungei Besi

$\delta C^{13}=-29.3 \%$

Dark-brown peat forming deposit ca. $2 \mathrm{ft}$ thick above interstratified mud and sand at alt. ca. $55 \mathrm{ft}$ and $150 \mathrm{ft}$ WSW of Samples NPL-143, NPL-144.

General Comment (N.S.H.): results indicate that much of deposit at Sungei Besi is pre-Holocene, most probably Pleistocene in age. NPL143 gives age equivalent to Late Pleistocene. Results insufficient to bear any general theory of age and nature of tin-bearing alluvium in Selangor but are consistent with view that deposits formed during period of rejuvenation of river systems by lowering of sea level during glacial periods of Pleistocene. Only other direct evidence of age of alluvium comes from pollen analysis of samples from mine made by Brunei Shell Petroleum Co. Ltd., Brunei. Within rich, well-preserved pollen flora, only firm indication was trisaccate grain of Podocarpus imbricatus type, known in Borneo only from late Pliocene and younger rocks (Mohammed bin Ayob, unpub. thesis, Univ. of Malaya, 1965). Results show that part of deposit is young enough to be dated by radiocarbon method, and indicates that further work could be valuable. 
Date lists:
GSC VI
GrN VI
NPL III
NPL IV
NPL V

\author{
Lowdon, Fyles, and Blake, 1967 \\ Vogel and Zagwijn, 1967 \\ Callow, Baker, and Hassall, 1965 \\ Callow, Baker, and Hassall, 1966 \\ Callow, and Hassall, 1968
}

\section{REFERENCFS}

Callow, W. J., Baker, M. J., and Hassall, G. I., 1965, National

radiocarbon measurements III: Radiocarbon, v. 7, p. 156-161. 1966, National Physical Laboratory radiocarbon measurements IV: Radiocarbon, v. 8, p. $340-347$.

Callow, W. J. and Hassall, G. I., 1968, National Physicai Laboratory radiocarbon measurements V: Radiocarbon, v. 10, p. 115-118.

Coope, G. R. and Sands, C. H. S., 1966, Summ. Progr. Geol. Survey for 1964, p. 53-54. Donovan, D. T., 1962, Sea levels of the Last Glaciation: Geol. Soc. America Bull., v. 73 , p. $1297-1298$.

Fairbridge, R. W., 1954, Quaternary eustatic data for W. Australia and adjacent states: Pan Indian Sci. Cong., Perth, 1954, Pr. sec. F, p. 64-84.

Lowdon, J. A., Fyles, J. G., and Blake, W., Jr., 1967, radiocarbon dates VI: Radiocarbon, $\mathrm{V}$. 9, $\mathrm{p}$. McArthur, W. M. and Bettenay, E., 1960 , The dialia. Commonwealth Sci. and Ind. Res. Organization Soil. Pub. no. 16.

Nichols, H., 1967, Pollen diagrams from sub-arctic central Canada: Science, v. 155, no. 3770 , p. $1665-1668$.

Pennington, Winifred, 1964, Pollen analyses from the deposits of six upland tarns in the Lake District: Roy. Soc. [London], Philos. Trans. B, v. 248, no. 746, p. 205-244 the Lake District: Roy. Soc. [London], some post-Glacial vegetation diversities at 1965, The interpretation of some post-Groc., B, v. 161, p. 310-323. different Lake District sites: Roy. Soc. [London] Proc., B, v. 161, P.

Stead, I. M. and Dymond, D. P.,

Antiquity, v. 33, p. 208-213. 1967, Groningen radiocarbon dates VI: Radiocarbon,

Vogel, I. C. and Zagn v. 9, p. 63-106. 